Original research article

\title{
Volunteering of people with disability
}

\author{
Aneta Marková ${ }^{1,2}$ \\ ${ }^{1}$ University of South Bohemia in České Budějovice, Faculty of Health and Social Sciences, Institute of Social and Special-paedagogical Sciences; \\ Faculty of Education, České Budějovice, Czech Republic \\ ${ }^{2}$ Charles University, Faculty of Humanities, Department of Civil Society Studies, Prague, Czech Republic
}

\begin{abstract}
This article deals with the volunteering of people with disability. Currently, this issue is becoming of interest to both the expert and nonexpert population. The introduction focuses on the clarification of the research and points out the studies that deal with this issue. The crucial part of this article is in the results of the research that was carried out as the author's dissertation.

The goal was to clarify what factors affect the participation of people with disability in volunteering from the point of view of volunteers with disability. We chose the method of Strauss and Corbin's Grounded Theory. We used it to analyze 25 interviews with volunteers with disability.

The interview analysis showed that five main factors affected the participation of people of disability in volunteering. The first factor included the advantages of volunteering for volunteers, the second were barriers from volunteers, organizations, the third included the presence or absence of a social role, the fourth was social unfulfilment and the fifth was activation. The final phase of the analysis showed that the main issue for volunteers with disability was the lack of social fulfilment (which is based on the presence or absence of a specific social role), which is significant for a volunteer with disability. Specific roles include the role of a parent, an employee, a partner or a fullyfunctioning member of the society. The results in the concluding discussion are compared with Wolfensberger's Social Role Valorization Theory.
\end{abstract}

Keywords: Disability; People with disability; Grounded Theory; Inclusive volunteering; Self-realization; Social role; Volunteering; Volunteers

\section{Introduction}

Volunteering, which can be characterised as non-obligatory and non-paid work outside one's own family (Frič et al., 2010), is a significant social and economical element in human society (Frič and Vávra, 2012; Pospíšilová and Marková, 2017). Studies show that volunteering is beneficial for society, situations or volunteering objectives as well as volunteers (Frič et al., 2010; Lim and Laurence, 2015). The growing number of studies that deal with volunteering was the basis for the public focus on the impacts of volunteering on the volunteer. It is stated that volunteering is beneficial for volunteers in many areas, e.g. more social contact, improvements in communication or acquiring working habits (Einolf and Chambré, 2011; Putnam, 1993).

Based on volunteering advatages for volunteers, (Marková, 2018) there are several possibilities to use volunteering primarily for the impacts on volunteers. Contemporarily, many programmes that are focused primarily on the effect of volunteering on volunteers are carried out. An example is the support of volunteering of seniors. They can develop or gain new social contacts, which helps mitigate against potential social isolation (Dusseljee et al., 2011; Ho, 2017). Volunteering of people after serving a sentence or volunteering of socially ex- cluded people is also supported. They gain new working habits and moderate socially undesirable behaviour (Nicholson and Cooper, 2013; Smith et al., 2004). Volunteering is thus an instrument for changing certain behaviours.

Miller et al. (2002; 2011) dealt with the volunteering of people with intellectual and developmental disorders. It was the first time a study was focused on volunteering of people with disability. Their conclusions show that volunteer co-ordinators say that volunteering is beneficial for people with intellectual and developmental disorders, and it helps them to develop skills, habits and experiences that they can use in other areas of their life (Miller et al., 2002). This opened up the issue of the volunteering of people with disability and inspired other studies that specifically dealt with the volunteering of people with disability (who were divided into groups by disability). Arbuckle and Herrick (2006), Beyer et al. (2016), Choma and Ochocka (2005), O’Brien et al. (2011) or Stroud et al. (2010) deal with intellectual and developmental disorders. Physical disorders are dealt with by e.g. Hyassat et al. (2016), Lindsay and Yantzi (2014) or van Mechelen et al. (2008). Sensory processing disorders are dealt with by Hitchings et al. (1998), and Miller et al. (2003) also mention them.

It is interesting that most studies so far include respondents who are in close contact with volunteers with disability. The provided information about the volunteering of people

\footnotetext{
* Author for correspondence: Aneta Marková, University of South Bohemia in České Budějovice, Faculty of Health and Social Sciences, Institute of Social and Special-paedagogical Sciences, Jírovcova 1347/24, 37004 České Budějovice, Czech Republic; e-mail: amarkova@zsf.jcu.cz; http://doi.org/10.32725/kont.2020.013 
with disability can be provided by co-ordinators of volunteers, family members or experts (e.g. doctors, social workers or special pedagogues). Studies that deal with people with disability and report on their volunteering activities are very sporadic. This article attempts to address this scarcity and provide at least some partial information about the factors that affect the volunteering of people with disability. This study was a part of the author's dissertation research.

\section{Materials and methods}

The main goal of this study was to clarify what factors (in this article the term "factor" is the equivalent of the term "agent") are included in terms of the participation of people with disability in volunteering from the point of view of volunteers with disability. Considering the fact that this was a new and so far unexplored phenomenon, we chose the qualitative method, specifically the method of Grounded Theory by Strauss and Corbin. Based on this research design, it is not necessary to have a research question (Cho and Lee 2014; Glaser and Holton, 2004) but we asked the following question for a better structure: From the point of view of volunteers with disability, what factors are included in the participation of people with disability in volunteering? Nevertheless, we did not only focus on the research question but on monitoring the volunteering of people with disability as a whole. The research question presents the direction of the study.

The target group included volunteers with disability. However, the research required the group to be specified. In this research, the term volunteering corresponded with Dekker and Halman (2003), who established a wider definition of volunteering: a volunteer is a person who willingly (and with no demands of a reward) performs an activity for the benefit of others who are not members of his or her family. The term disability corresponded with the 10th revision of the International Classification of Diseases - a disability is the damage of organs or its functions (ICD-10). This study was carried out in the Czech Republic, so all respondents were recognized as person with disability according to $\S 67$ of the Act No. 435/2004 Coll. on employment. This was because they were people who were recognized as 1st and 3rd degree invalids by the authority of social security. The main criteria for respondents to be included in the group were objective limitations and the subjective self-perception of the person with disability. This research agrees with the definition of disability in The Disability Discrimination Act.

This study included 25 respondents and another two who confirmed data saturation. The characteristics of the 25 respondents are presented in Table 1 . Its content was published with regards to research ethics so that the respondents' personal data were protected. The respondents were defined by codes instead of names: D - the group of volunteers, F/M defined whether it was a woman (F) or man (M), and the numbers 01-25 defined the order of interviews.

We carried out interviews with the volunteers with disability, which, on average, lasted 61 minutes. The interviews were transcribed and analyzed using the Grounded Theory of Strauss and Corbin (1999), i.e. an open, axial and selective coding (Marková, 2017).

\section{Results}

Using the interviews and their analysis, we discovered two factors that affected the volunteering of people with disability.

\section{Table 1. Basic demographic data about the respondents}

\begin{tabular}{lr} 
Number of participants & 25 \\
women & 18 \\
men & 7 \\
\hline Average age & 39 \\
\hline Marital status & \\
single & 13 \\
in partnership & 2 \\
married & 6 \\
divorced & 2 \\
widowed & 2 \\
\hline Parenthood & \\
yes & 13 \\
no & 12 \\
\hline Employment & \\
common employment & 7 \\
supported employment & 4 \\
unemployed & 14 \\
\hline Health disorder & \\
intellectual & 3 \\
sensory & 9 \\
physical & 12 \\
combined & 1 \\
\hline Achieved level of education & \\
university & \\
secondary/high school & \\
secondary vocational & \\
primary & 2 \\
\hline
\end{tabular}

The first and most obvious factor was the category of "advatages", i.e. the advatages of volunteering for volunteers with disability. In this category, volunteers with disability most frequently described their personal growth (e.g. self-relization, resetting values, realizing their value) or gaining social relationships. Volunteers with disability often described limiting social relationships before volunteering, and then the gaining of new contacts when they started volunteering.

"Well, I did not have many friends before (...) it is spending leisure time, meeting new people, which there was a lot of, the organization brings many people together and connects them. So you can meet a lot of people. For example, those who have a similar opinion on the world ..." (DZ03).

"I don't like being only at home ... and go to doctors and I wanted to be among people in fact" (DZ15).

Volunteering also had a positive impact on the volunteers' health. Some respondents stated that volunteering only helped their health because they had to get up and do something.

"The feeling of usefulness; that is what gets you on your feet" (DZ07).

However, the category of advatages included subcategories, such as work (gaining new experiences, skills, knowledge or social contacts that lead to new employment) or gaining a new social role that is of value.

"Well, I was, I mean, I still am (laughing) a mom but something was missing. (...) Now I say I am a volunteer and I feel more accepted" (DZ08).

The complete overview of found advatages of volunteering for volunteers can be seen in Table 2 .

The category of advatages of volunteering appears to be a significant factor that affects the start of volunteering, and later the volunteering itself.

Another factor that affects the volunteering of people with disability is the presence or absence of barriers. Based on the 
Table 2. Identified disadvantages of volunteering for volunteers with disability

\begin{tabular}{|c|c|c|}
\hline Experience & & $\begin{array}{l}\text { new experiences, travelling, communication in foreign languages } \\
\text { "coming out of their shell" } \\
\text { expressing their opinions, debating, discussing, sharing a new } \\
\text { environment, new situations, having the role of a helper } \\
\text { participating in lectures, courses, trainings and various activities }\end{array}$ \\
\hline \multirow[t]{2}{*}{ Skills and knowledge } & $\begin{array}{l}\text { Managerial } \\
\text { skills }\end{array}$ & $\begin{array}{l}\text { fundraising, propagation, writing projects } \\
\text { time-management, organizing activities and schedules } \\
\text { orientation in the field } \\
\text { independence, co-operation with a team, managing people/teams } \\
\text { punctuality, precision }\end{array}$ \\
\hline & $\begin{array}{l}\text { Practical } \\
\text { skills }\end{array}$ & $\begin{array}{l}\text { skilfulness, accuracy } \\
\text { knowledge of a specific system and methods of doing things, such as how things work }\end{array}$ \\
\hline Self-relization & & $\begin{array}{l}\text { discovery of one's own skills and abilities } \\
\text { discovery of one's preferences and values } \\
\text { preference of a social group } \\
\text { gaining the ability of self-assessment }\end{array}$ \\
\hline Health - mental & & $\begin{array}{l}\text { improving confidence } \\
\text { feeling useful } \\
\text { joy, entertainment, satisfaction, rest } \\
\text { life fulfilment, good feelings, admiration from those surrounding them } \\
\text { meaningfulness and time meaningfully spent } \\
\text { gaining confidence, decreasing self-pity } \\
\text { new energy, increased resistance }\end{array}$ \\
\hline Health - physical & & $\begin{array}{l}\text { decreased focus on physical problems } \\
\text { more movement }\end{array}$ \\
\hline Social relationships & & $\begin{array}{l}\text { gaining new contacts } \\
\text { sharing experiences, skills, advice, inspiration } \\
\text { "opportunity to be among people", "opportunity to be somewhere together" } \\
\text { sharing information - acquiring work opportunities }\end{array}$ \\
\hline Social identity & & $\begin{array}{l}\text { gaining a new social role } \\
\text { belonging in a specific group and identifying with it }\end{array}$ \\
\hline
\end{tabular}

interviews, we were able to identify the most frequent barriers that affect the participation of people with disability in volunteering. Such barriers can be classified by a few criteria. Tables 3 and 4 show two crucial ways of classification. The first focuses on the area that a barrier comes from. The second shows barriers by the type of disorder.

A barrier can be classified by where the volunteers come from. Considering the fact that most of therespondents included in the research participated in formal volunteering, the

Table 3. Identified barriers from the volunteer's with disability point of view

\begin{tabular}{lll}
$\begin{array}{l}\text { Barriers from } \\
\text { volunteers }\end{array}$ & $\begin{array}{l}\text { Barriers from the } \\
\text { organization }\end{array}$ & $\begin{array}{l}\text { Barriers from } \\
\text { society }\end{array}$ \\
\hline $\begin{array}{l}\text { Low level of work } \\
\text { experience }\end{array}$ & $\begin{array}{l}\text { Lack of existing } \\
\text { opportunities }\end{array}$ & Prejudice of society \\
\hline $\begin{array}{l}\text { Low or unclear } \\
\text { motivation }\end{array}$ & $\begin{array}{l}\text { Low level of flexibility } \\
\text { of volunteering }\end{array}$ & $\begin{array}{l}\text { Creating the role of } \\
\text { usefulness }\end{array}$ \\
\hline Worries and fear & $\begin{array}{l}\text { Unclear work } \\
\text { methodology }\end{array}$ & \\
\hline $\begin{array}{l}\text { Inadequate } \\
\text { expectations }\end{array}$ & Prejudice & State policy \\
\hline Their disability & $\begin{array}{l}\text { Unadjusted } \\
\text { conditions: } \\
\text { personnel, technical, } \\
\text { administrative, } \\
\text { architectural }\end{array}$ \\
\hline $\begin{array}{l}\text { Previous negative } \\
\text { experience }\end{array}$ & \\
\hline $\begin{array}{l}\text { Low or inadequate } \\
\text { self-confidence }\end{array}$ &
\end{tabular}

classification came from volunteers, organization and society. Interview analyses show that a low level of self-confidence, their own approach to their disability or worries and fear are included in the main barriers that affect the start of volunteering, and later the volunteering itself. The barriers from organizations are related to personnel, technical, administrative, architectural and organizational (assessed by the volunteers themselves). In this category, there are barriers such as the lack of existing volunteering opportunities, the lack of an unadjusted environment for volunteering, or prejudice from organization members. The respondents also mentioned prejudice as a societal barrier. The interview analyses showed that volunteers with disability perceived prejudice as a bigger problem, which affected volunteering. This helped to create the third group of barriers, i.e. from society. Volunteers with disability mentioned that they felt limited by society and they relate these barriers with the social setting and the society's view of people with disability and state policy (Table 3).

Another barrier classification was related to the specific disability type, which is shown in Table 4.

Based on interview analyses, "advantages" and "barriers" were the first factors to reveal themselves that affect volunteering. However, other factors started to surface in other phases of the interview analyses, which affect the start of volunteering of volunteers with disability. One of those factors is the presence or absence of a specific social role, which is something that respondents consider crucial at the moment.

The interview analyses showed three types of social roles: (a) performed social role; (b) absent social role; (c) given social role. In the first two cases, it is the same group of social roles 
Table 4. Examples of identified barriers by a volunteer's disability type

\begin{tabular}{llll} 
Visual disorder & Hearing disorder & Intellectual disorder & Physical disorder \\
\hline Space orientation & Reading lips & Situation complexity & Commuting \\
\hline Commuting & Difficulty speaking & The need for illustration & Building accessibility \\
\hline Text messages & Phone calls & $\begin{array}{l}\text { The complexity of written } \\
\text { announcements }\end{array}$ & Lower/higher sensitivity \\
\hline The internet & Voice proclamation and warnings & Strong emotional experience & Difficult communication \\
\hline Illustration & The need for visualization & Commuting & Spatial imagination \\
\hline The presence of an assistance dog & $\begin{array}{l}\text { Difficult communication and } \\
\text { premature feeling of fatigue }\end{array}$ & Self-service & $\begin{array}{l}\text { Problems with fine/gross motor } \\
\text { skills }\end{array}$ \\
\hline
\end{tabular}

but the difference is in the fact whether this social role is performed or not. The interview analyses identified the following social roles:

- the role of a volunteer;

- the role of an employee;

- the role of a parent;

- the role of an offspring/child;

- the role of a full-functioning society member;

- the role of a useful person;

- the role of a student.

"Like, yeah, I have a job, but I wanted... you know... to be a useful person" (DM09).

"While I'm single, I have time for this volunteering. After that, I don't know if it will be possible to fit both together. (...), I'd like to have a family but I can't do it by myself" (DZ23).

Volunteers with disability stated that having a specific social role inspires someone to volunteer. On the other hand, interview analyses show that the absence of a specific social role inspires volunteering. One example of this is the role of a parent. If a volunteer with disability is a parent, this role inspires them to volunteer in the playgroups of their children. On the other hand, the absence of the social role of a parent gives a person sufficient time and space to start volunteering. It is interesting that not only have volunteers with disability experienced negative feelings caused by the absence of a social role, but they have also felt endangered or they have perceived the direct presence of a different social role that they considered to be socially negative. We could say that volunteers with disability perceive the absence of a specific social role as being ascribed to a different, negative role. The interview analyses identified the following negatively perceived social roles:

- the role of a person with disability;

- the role of a freeloader;

- the role of an unemployed person;

- the role of a childless person;

- the role of a dependent person;

- the role of an uneducated person.

As we have made clear, volunteers with disability felt endangered by accepting a specific social role that is generally considered negative. This factor has played a crucial role in their life and affected the start of their volunteering up to a certain point. The interview analyses showed that the feeling of the absence of a specific social role was the reason for the volunteers with disability to start volunteering.

"The label 'disabled' is terrible. Everybody thinks that all I need is money. Not that I don't need it, who doesn't? But I mainly want to live like everybody else" (DM06).

"I'm not an ideal sister but who is today, right, when there is always something... And, like, I'll never be an ideal partner ... but for somebody... for somebody maybe yes... but... a person never has to be ideal but such a person that isn't ashamed of themselves" (DZ23).

We also identified a factor called "insufficient social fulfilment”. Insufficient social fulfilment presents limited opportunities for social fulfilment. There are also insufficient opportunities for performing full employment, making new social contacts or having a specific social role. This feeling of lack - which is associated with a certain fulfilment or social tasks - showed up as crucial. It was also shown that the feeling of this lack brought about strategies for its management. The revealed management strategies were named: activation, helplessness, self-defense and critique. Based on selective coding, it was shown that the factor that caused volunteering was activation.

It was also shown that there were obvious factors that affected the start of volunteering, and the later performance of volunteering of people with disability (the advatages and barriers in volunteering), as well as subjective or less obvious factors (presence or absence of a specific social role, presence or absence of social fulfilment and activation, i.e. active management strategy). Interview analyses showed these five factors as crucial regarding the participation of people with disability from the point of view of volunteers with disability. This answered the research question that we asked at the beginning of this study. In correspondence with the Grounded theory, we created the following theory:

Volunteering is one of the opportunities for people with disability to experience self-fulfilment. This way is based on activation (during the subjective perception of insufficient social fulfilment). In this case, insufficient social fulfilment is based on the presence or absence of a specific social role that a person with disability considers significant.

The resulting theory is shown in Chart 1 . The following paragraphs specify the relationships that led to its formation.

Insufficient social fulfilment is based on individual cause and environmental conditions that directly affect performing or having a specific social role. Individual causes include the disorder, health condition, education, self-reflection, personal approach to the disorder, and partial education of the given person. Environmental conditions include (a) barriers, i.e. the way that a person deals with them; (b) family, i.e. its presence or absence or support; (c) limited opportunities, i.e. whether a person is confronted with a limitation, and (d) social setting, i.e. how society perceives disabilities.

The analysis shows that, according to people with disability, individual causes and environmental conditions affect the presence or absence of a specific social role, i.e. having a positively assessed social role, such as the role of a parent, employee or a "contributor to society", i.e. a "useful member of society". In our group of respondents, volunteers with disabili- 


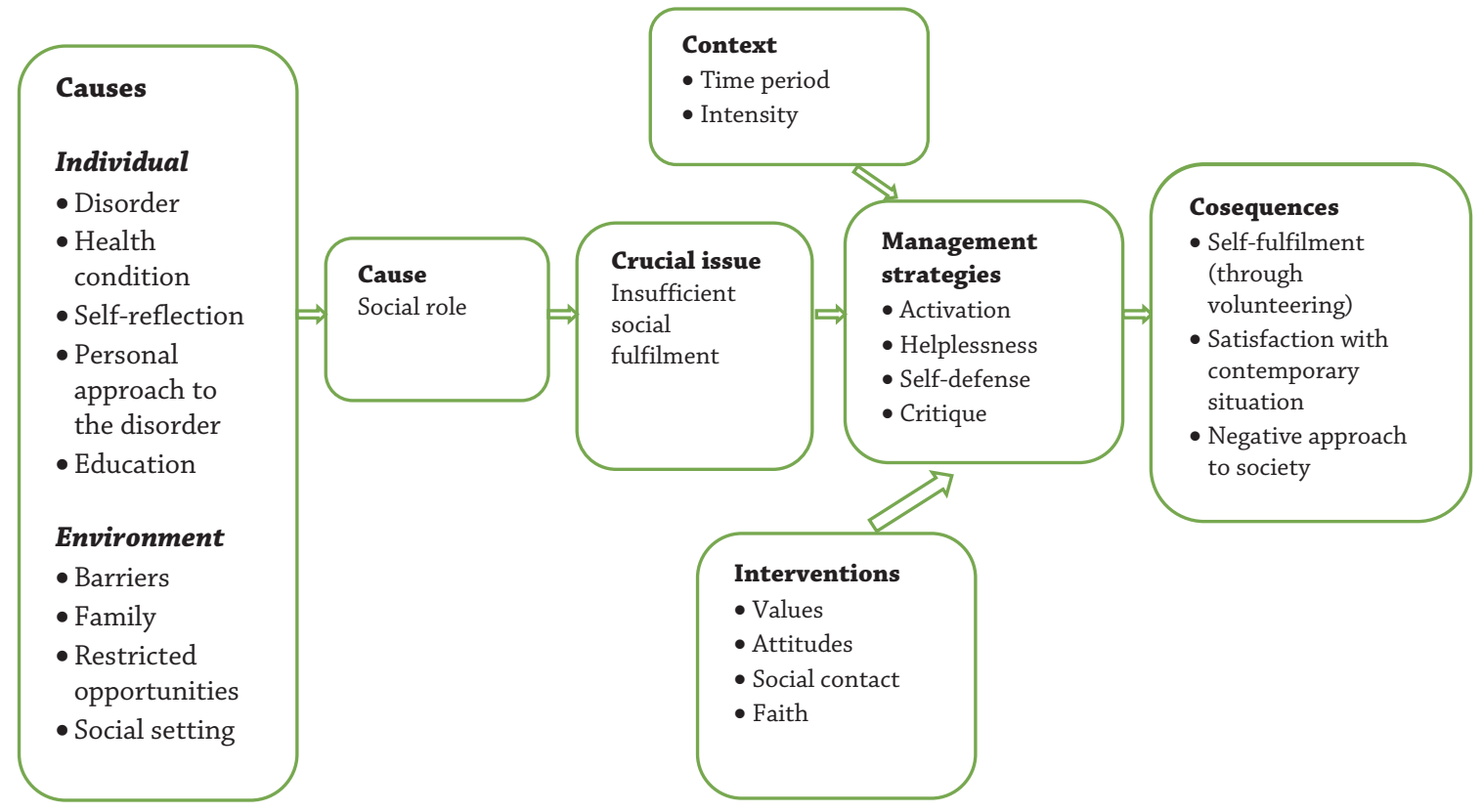

Chart 1. Illustration of the relationships in the crucial theory or the paradigmatic model

ty do not have a full social role, which brings about a subjective perception of insufficient social fulfilment. The solution to insufficient social fulfilment is brought about by strategies that individuals with disability use to manage this situation. Our group of respondents agreed that activation was the most important. This means that people with disability try to activate themselves, which helps them to overcome or eliminate insufficient social fulfilment. A consequence of personal activation is self-fulfilment, which, in our group, is shown by starting and performing volunteering.

"Nobody wanted to employ me, so it was difficult. (...) I needed to be useful. And I feel useful here" (DZ13).

The most important factor was insufficient social fulfilment that was based on the absence of a specific social role that a volunteer with disability considered crucial. The analysis showed that volunteers with disability did not have the roles of employees, parents or a full member of society. People with disability use volunteering to compensate for the lack of a different social role or to make up for a lost social role, which corresponds with the conclusions of Caro and Bass (1997) and Staines (1980).

“... I used to have a good job, I worked in a financial office, so I had a good job... (...) the job fulfilled me, I had no worries, I had money. And it's one with the other... (...) and as I lost the job, I wanted to do something and not do nothing (...) it is difficult not to have the role of an employee (...) I found the organization on the Internet and went to the centre to see what they had there (...) why do I do this? Well, I mainly feel useful" (DZ16).

The research conclusions show that the volunteering of people with disability is influenced by five factors: (1) advatages of volunteering; (2) barriers; (3) presence or absence of a social role; (4) insufficient social fulfilment and (5) activation. It has also been shown that volunteering plays a significant part in the lives of volunteers with disability because it helps soften the feeling of insufficient social fulfilment.

\section{Discussion}

The objective of this research was to clarify what factors were included as causes of the participation of people with disability in volunteering (from the point of view of volunteers with disability). The analyses of the interviews with volunteers with disability showed that the first factor that influenced volunteering was the advatages of volunteering for the volunteers themselves. These advatages were new experience (e.g. new experiences, confronting their own opinions, experience with a new environment or new situation), gaining new skills and knowledge (managerial skills, expert skills, practical skills), self-reflection (e.g. realizing one's abilities or gaining the understanding of one's self). Other advantages included improvements to mental health (e.g. joy, entertainment, life fulfilment, increased resistance, gaining the feeling of usefulness) or improvement of physical health (e.g. improved or higher-quality physical activities, "moving"). The advatages also included social relationships (e.g. gaining new contacts, sharing experiences) and social identity (e.g. identification with a group, or the feeling of belonging in a specific social group).

The second factor that affects the participation in volunteering are barriers from volunteers with disability - as well as from society. The analyses showed that individual causes (e.g. low level of work experience, fear, low self-confidence, limitations of one's disability) play a role in volunteering, as well as environmental conditions (e.g. insufficient number of existing opportunities, unclear work methodology, low flexibility in volunteering, prejudice or unsupportive state policy).

The third identified factor was the social role that volunteers had or missed. Up to a certain point, a social role enabled involvement in volunteering and the absence of a social role inspired it. This factor was mostly seen in the role of a parent, 
employee, student, and the role of a full/useful society member.

The fourth identified factor was called insufficient social fulfilment. Insufficient social fulfilment is the subjective feeling that a person is insufficiently useful for society and, very frequently, it is associated with a specific time period and performing a specific social role. There are two associated factors: a specific social role that inspires volunteers to volunteer, and the absence of a specific social role associated with insufficient social fulfilment that affects participation in volunteering.

The fifth identified factor was activation or active management strategy of insufficient social fulfilment.

Not only do these findings show what factors are involved in the volunteering of people with disability, but they also tell us something about volunteers with disability. They are people who, despite their difficulties, tend to be active and useful for society. It is possible to assume that if a person with disability is experiencing the feeling of insufficient social fulfilment, they miss a specific social role that they consider crucial, see the advatages of volunteering, do not feel large barriers to starting to volunteer and are active in solving the feeling of insufficient social fulfilment, then they will tend to start volunteering.

A comparison of the results of this research to existing theories shows that there could be a larger extent of the volunteering of people with disability, especially if we relate our findings to Wolfensberger's Social Role Valorization Theory $(2011 \mathrm{a}, \mathrm{b})$. At the beginning of the process of devaluation, there is a primary decreased performance caused by a disability. According to Siška (2005), this process starts with primary decreased performance being burdened by prejudice and ignorance. Volunteers with disability identified prejudice as one of the crucial barriers in relation to participation in volunteering (i.e. barriers from organizations and society). This causes expectations that a person can be of service to society to be decreased. This phase of the devaluation process corresponds with the identified barrier of insufficient existing opportunities for volunteering. The process of devaluation includes the fact that deceased expectations cause a person to have limited opportunities because it is assumed that their contribution will be small or none, thus it is not effective to encourage them (Šiška, 2005). Volunteers with disability identified this attitude by considering their participation in volunteering because of decreased opportunities. However, limited opportunities cause a person to gain negative social experience, which is another element that appeared in the interviews. Volunteers with disability spoke of societal barriers and specific organizations as well their negative experience with society. According to Wolfensberger, negative experience leads to secondary decreased performance, which devalues a person (Šiška, 2005). If we relate our findings to Wolfensberger's Social Role Valorization Theory, volunteers with disability fight their devaluation by volunteering.

\section{Conclusions}

In conclusion, it is necessary to say that this research has its limitations - which up to a certain point can affect the resulting theory. The first limitation is the target group, which only consisted of volunteers with disability at the time. Another limitation was the wide extent of the research goal. This happened because it is a new and unstudied phenomenon and a narrow focus could have eliminated information that could otherwise have been gained. However, the extent of our goal hindered the analytic process up to a certain point, which could have caused an inaccurate interpretation of the findings gained. There should be further studies regarding this issue; which focus on the volunteering of people with disability and either confirm or disprove the resulting theory.

We suggest a quantitative study focused on specifying volunteers' with disability motivation for volunteering, or the identification of the barriers in the volunteering of people with disability who are yet to volunteer. We also suggest research that involves comparing the life paths of person/ volunteer with disability volunteers and those without a disability - which could show the differences in the approach to volunteering.

\section{Conflicts of interests}

The author has no conflict of interests to declare.

\title{
Dobrovolnictví a dobrovolnická činnost osob s postižením
}

\begin{abstract}
Souhrn
Článek se věnuje tématu dobrovolnictví a dobrovolnické činnosti osob s postižením, které se v současné době dostává do povědomí odborné i laické veřejnosti. V úvodu se článek soustředí na objasnění výzkumného problému, přičemž poukazuje na výzkumy, jež se v této oblasti objevují. Stěžejní část článku představuje výsledky z výzkumného šetření, který byl realizován v disertační práci autorky.

Výzkumným cílem bylo objasnit, jaké faktory se podílejí na účasti osob s postižením v dobrovolnické činnosti z pohledu samotných dobrovolníků s postižením. Pro naplnění výzkumného cíle byla zvolena metoda Zakotvené teorie verze Strauss a Corbin. V rámci této metody bylo analyzováno 25 rozhovorů s dobrovolníky s postižením.

Analýza rozhovorů ukázala, že existuje pět hlavních faktorů, které se podílejí na účasti osob s postižením v dobrovolnické činnosti. První faktor byl pojmenován jako přínos z dobrovolnické činnosti pro dobrovolníky, druhý faktor představují bariéry a to bariéry ze strany dobrovolníka, organizace nebo společnosti, dále se jedná o faktor př́tomnosti nebo nepřítomnosti sociální role, čtvrtým faktorem je nedostatek společenského uplatnění a pátým faktorem je aktivizace. Při finální fázi analýzy rozhovorů se ukázalo, že ústředním jevem dobrovolnické činnosti osob s postižením je nedostatek společenského uplatnění, který vychází z př́tomnosti nebo naopak z nepřítomnosti konkrétní sociální role, jež je pro dobrovolníka s postižením v daný okamžik významná. Jedná se např́iklad o roli rodiče, pracujícího, o roli partnera nebo roli plnohodnotného člena společnosti. Výsledná zjištění jsou v závěrečné diskusi konfrontována s Wolfensbergerovou teorií devalvace člověka.
\end{abstract}

Klíčová slova: dobrovolníci; dobrovolnictví; Grounded Theory; inkluzivní dobrovolnictví; osoby s postižením; postižení; sebeuplatnění; sociální role 


\section{References}

1. Act No 435/2004 Sb., o zaměstnanosti, ve znění pozdějších předpisů. In: Sbírka zákonů České republiky, částka 143/2004.

2. Arbuckle M, Herrick Ch (2006). Child and adolescent mental health: Interdisciplinary systems of care. USA: Jones \& Bartlett Learning, $424 \mathrm{pp}$.

3. Beyer SR, Meek AJ, Davies A (2016). Supported work experience and its impact on young people with intellectual disabilities, their family and employers. Advance in Mental Health and Intellectual Disabilities 10(3): 207-220. DOI: 10.1108/ AMHID-05-2014-0015.

4. Caro FG, Bass SA (1997). Receptivity to volunteering in the immediate postretirement period. Journal of Applied Gerontology 16(4): 427-442. DOI: $10.1177 / 073346489701600403$.

5. Cho JY, Lee E-H (2014). Reducing confusion about grounded theory and qualitative content analysis: Similarities and differences. The Qualitative Report 19(32): 21.

6. Choma BL, Ochocka J (2005). Supported volunteering A community approach for people with complex needs. Journal on Developmental Disabilities 12(1):1-18.

7. Dekker P, Halman L (Eds) (2003). The Values of Volunteering: Cross-cultural perspectives.New York: Kluwer Academic Press/ Plenum Publishers, $226 \mathrm{p}$.

8. Dusseljee JC, Rijken PM, Cardol M, Curfs LM, Groenewegen PP (2011). Participation in daytime activities among people with mild or moderate intellectual disability. J Intellect Disabil Res 55(1): 4-18. DOI: 10.1111/j.1365-2788.2010.01342.x.

9. Einolf Ch, Chambré S (2011). Who volunteers? Constructing a hybrid theory. International Journal of Nonprofit and Voluntary Sector Marketing. Int. J. Nonprofit Volunt. Sect. Mark. 16: 298-310. Published online in Wiley Online Library (wileyonlinelibrary.com). DOI: 10.1002/nvsm.429.

10. Frič P, Pospíšilová T, et al. (2010). Vzorce a hodnoty dobrovolnictví v české společnosti na začátku 21. století. Praha: Agnes, $263 \mathrm{p}$.

11. Frič P, Vávra M (2012). Tři tváře komunitního dobrovolnictví: neformální pomoc, organizovaná práce a virtuální aktivismus. Praha: Agnes. $138 \mathrm{p}$.

12. Glaser B, Holton J (2004). Remodeling Grounded Theory. Qualitative Social Research 5(2). DOI: 10.17169/fqs-5.2.607.

13. Hitchings WE, Luzzo DA, Retish P, Horvath M, Ristow RS (1998). Identifying the career development needs of college students with disabilities. Journal of College Student Development 39(1): 23-32.

14. Ho H-Ch (2017). Elderly volunteering and psychological well-being. International Social Work 60(4): 1028-1038. DOI: 10.1177/0020872815595111

15. Hyassat M, Alqahtani A, Alzaareer (2016). The Participation of Male Youth with Disabilities in Voluntary Work in Tabuk City: A Qualitative Study. Dirasat: Educational Science 43(1): 1587-1599.

16. Lim C, Laurence J (2015). Doing good when times are bad. The British Journal of Sociology 66: 319-344. DOI: 10.1111/14684446.12122

17. Linday S, Yantzi N (2014). Weather, disability, vulnerability, and resilience: exploring how youth with physical disabilities experience winter. Disabil Rehabil 36(26): 2195-2204. DOI: 10.3109/09638288.2014.892158.
18. Marková A (2017). The "inclusive volunteering" phenomenon: Research into the volunteering of people with disabilities. Kontakt 20(1): 48-56 DOI: 10.1016/j.kontakt.2017.10.003.

19. Marková A (2018). Inkluzivní dobrovolnictví: Dobrovolnická činnost osob s postižením. Praha. 245 p., disertační práce. Univerzita Karlova v Praze. Vedoucí práce: Tereza Pospíšilová.

20. Miller A, Simpson B, Lieben J, Simpson BJ, et al. (2011). Understanding The Role of Volunteerism in Creating Social Inclusion. South West Communities Resource Centre. [online] [cit. 2019-09-20]. Available from: http://swcrc.ca/wp-content/ uploads/2013/09/Understanding-the-Role-of-Volunteerismin-Creating-Social-Inclusion-Final-Report-for-SWCRCSeptember-2011.pdf

21. Miller KD, Schleien SJ, Bedini LA (2003). Barriers to the Inclusion of Volunteers with Developmental Disabilities. The Journal of Volunteer Administration 21(1): 25-30.

22. Miller KD, Schleien SJ, Rider C, Hall C, Roche M, Worsley J (2002). Inclusive volunteering: Benefits to participants and community. Therapeutic Recreation Journal 36(3): 247-259.

23. Nicholson L, Cooper SA (2013). Social Exclusion and People with Intellectual Disabilities: A Rural-Urban Comparison. J Intellect Disabil Res 57(4): 333-346. DOI: 10.1111/j.13652788.2012.01540.x.

24. O’Brien L, Burls A, Townsend M, Ebden M. (2011) Volunteering in nature as a way of enabling people to reintegrate into society. Perspect Public Health 131(2): 71-81. DOI: $10.1177 / 1757913910384048$

25. Pospíšilová T, Marková A (2017). Možnosti a limity inkluzivního dobrovolnictví. FORUM Sociální politiky 5(2): 12-19.

26. Putnam R (1993). Making Democracy Work. Civic Traditions in Modern Italy. Princeton: Princeton University Press. 280 p.

27. Šiška J (2005). Mimořádná dospělost. Praha: Univerzita Karlova v Praze, $100 \mathrm{p}$.

28. Smith JD, Ellis A, Howlett S, O’Brien J (2004). Volunteering for all? Exploring the link between volunteering and social exclusion. London: Institute for Volunteering Research. [online] [cit. 2016-05-02]. Available from: http://www.iriv-vaeb.net/ fichiers/Ressources\%20Europe/Volunteering\%20and\%20 social\%20exclusion-\%20UK\%202005.pdf

29. Staines GL (1980). Spillover versus compensation: a review of the literature on the relationship between work and nonwork. Human Relations 33(2): 111-129. DOI: $10.1177 / 001872678003300203$.

30. Strauss AL, Corbin J (1999). Základy kvalitativního výzkumu. Boskovice: Albert, $196 \mathrm{p}$

31. Stroud S, Miller KD, Schleien SJ, Merrill M (2010). Engaging Volunteers with Disabilities: A Qualitative Study. The International Journal of Volunteer Administration27(2): 75-86.

32. Van Mechelen MC, Verhoef M, Van Asbeck FV, Post MW (2008). Work participation among young adults with spina bifida in Netherlands. Dev Med Child Neurol 50(10): 772-777. DOI: 10.1111/j.1469-8749.2008.03020.x.

33. Wolfensberger W (2011a). Social Role Valorization and, or Versus, "Empowerment". Intellect Dev Disabil 49(6): 469-476. DOI: 10.1352/1934-9556-49.6.469.

34. Wolfensberger W (2011b). Social Role Valorization: A Proposed New Term for the Principle of Normalization. Intellect Dev Disabil 49(6): 435-440. DOI: 10.1352/1934-9556-49.6.435. 